결핵 및 호홉기질환 Vol. 18, No. 3, July, 1971

외국 중요 논문 초역

\section{Lysosome과 결핵 감염}

\section{Lysosome and Tuberculosis Infection}

Toida, I.R.

Abstracts of the Current Literature on

Tuberculosis \& Respiratory Diseases, Japan.

1971 5, 22; 1099

Lysosome에 관한 종설은 대단희 많지만 의의에도 결 핵갇염 과의 관계에 언급한 것은 별로 없다.

\section{Lysosome의 개념}

Lysosome이라는 명칭이 De Duve에 의해서 제창 된 것은 1955년이다. 동물세포 속에 세포핵 이의에는 $\mathrm{Mi}$ tochondria Microsome만이 있는 것이라고 했었으나 $\mathrm{De}$ Duve는 여러가지의 효소를 포합한 또 다른 과립이 존 재한다는 것을 발견한 것이고 이 과팁 즉 Lysosome은 서로 관련성이 없는 기질특이성을 가진 여러개의 (37종 이상) 가용성 가수분해 효소들이 주위의 세포기질과는 접측될 수 없는 상태로 Lipoprotein Membrane에 싸여 있는 것인데 보통으로는 활성이 잗재성으로 퇴여 있으 나 필요시에 혹은 세포가 파례 번화될 때에 각기 활성 을 나타낸다고 했다.

Lysosome은 생화학적, 기능적 관념에서 발견된 것이
고 형태학적으로 구별된 것이 아니며 그 형태는 여러가 지로 나타난다. 형태학적 연구에는 분획의 전자현미경 적 관찰과 Gomori의 acid phospatase 염색양성 과립 의 조직화학적 혹은 전자현미경적 관찰방법이 있다.

\section{Lysosome의 기능}

Lysosome은 산성 가수분해 호소의 집합체이니까 우 선 생각할 수 있는 것은 산성소화(acid digestion)이다. Phagocytosis 나 Pinocytosis (포위 현상에 의해서 수분 홉수가 되는 일) 때에는 이물은 세포막에 의해서 툴러 싸이여서 Phagosome을 형성하는데 한쪽에서는 ribosome에서 합성된 Lysosome 중의 가수분해 호소군이 역 시 막에 들러싸인체 Phagosome에게로 와서 두 과립은 응합되면서 가수분해호소군이 Phagosome 속으로 들어 가서 활동하게 된다.

Lysosome은 이 물질에 대해서 만 작용하는 것의 아니 고 괴사된 조직의 청소나 조직의 autolysis에도 큰 역할 을 하는 것이고 또 정상발육과정에 있어서도 예를 들먼 올챙이의 공지가 펄어질 때나 닭의 Müller's Canal의 성적분화에 있어서도 중요한 역활을 한다.

\section{Lysosome의 형성가 분포}

세포가 증대되는데 따라서 이 가팁체도 증가하며 DL-P-fluorophenylalanine이나 Puromycin과 같은 단 백합성저해제의 첨가나 Cyanide, Antimycin A. Anaerobiosis와 같은 호흡기능 혹은 해당작용저해제 에 의 해서 생산억제가 된다.

각 등물, 각 장기세 따라서 Lysosome의 분포량과 결 합 혹은 유리호소 활성도의 비율차도 있다.

\title{
Structural Model of 〈Lysosome〉
}

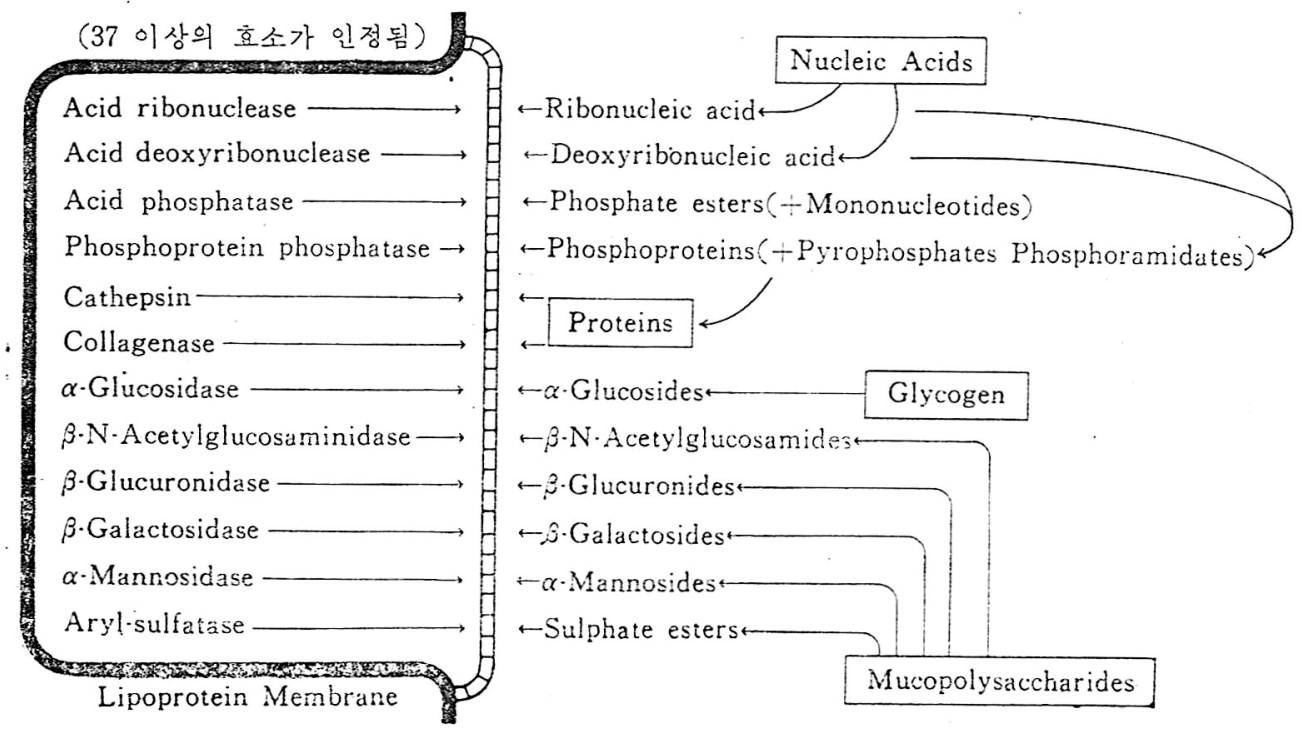


결핵 및 호홉기질찬. Vol. 18, No. 3, July, 1971

Functional Model of

〈Lysosome

\begin{tabular}{|l|l}
\hline Intact Lysosomes & (Enzymes bound and inaccessible) \\
& $\begin{array}{l}\text { Waring blendor } \\
\text { (조심스럽 게 살작 퀴 졌다) } \\
\text { Inadequate osmotic protection }\end{array}$ \\
$\begin{array}{cl}\text { Factors) } & \text { Freezing and thawing (녹이다) } \\
\text { Sonic vibration } \\
\text { Lecithinase. Proteinase } \\
\text { Autolysis } \\
\text { Fat solvents } \\
\text { Detergents }\end{array}$
\end{tabular}

Injured Lysosomes (Enzymes, soluble and accessible)

\section{Lysosome 기능부전에 의한 질병들}

1) Congenital dysphagocytosis (phagosome 형성부전)

2) Chédiak-Higaslhi syndrome (Lysosome 막의 결함)

3) Pompe's disease ( $\alpha$-glucosidase의 결손)

4) Hurler's syndrome (Gargolism)

( $\alpha$-L-fucosidase 혹은 $\beta$-galactosidase 결손)

5) Fabry's disease (Ceramide-trihexosidase 결손)

6) Gaucheirs disease (Glucocerebrosidase 결 손)

7) Metachromatic leucodystroply (Sulfatase A 결손)

8) Nieman-Pick's disease (splingomyelinase 결손)

\section{Lysosome과 세균감염}

셰균감염에 있어서 phagocytosris의 중요성은 말할 필 쇼도 없지만 륵히 이 중에서도 백혈구나 macrocyte의 특이한 과립은 lysosome이라는 것이 Cohn 등에 의해 서 증명되였다. 그런데 주의할 일은 세균대 lysosome의 관계는 일방적으로 세균에게 불리하고 생체에 유익하게 만 되는 것이 아너고 때로는 세균독소에 의해서 파괴된 백혈구 속에서 나오는 lysosome의 호소들은 세포를 lysis 시켜서 조직의 상해를 가져오계 될 수도 있는 것이 다. 그리고 또 결핵균의 경우에는 lysosome베 의해서 포위되여 있으면서도 균은 그대로 살아 있는 수도 있다 는 점은 룩히 주목 할 일이다.

\section{6. 결핵갑염과 Lysosome 효소활성}

결랙갑열시에 산성 phosphatase뢀성이 상승한다는 것 은 lysosome 발견 이전부터 잔 알려졌었다. 그런데 이 매의 호소활성도의 상승은 루로 할성도가 높은 세포의 삼출현상에 의한다고 할수 있다고 추측된다.

\section{Lysosome의 항균성 물질}

Lysosome은 산성 가수분해 호소 이외에도 몇가지의 찰균성 혹은 균증식겅지성 물질을 가지고 있다. 그러나 Intraccllular parasite의 대포인 결핵균이 Phagocyte 속 에서도 생존증식한수 있다는 점을 생각하면 이러한 항 군물질이 정상 생체 속에서는 별로 큰 역할을 못 한다 고 할수 있다.

\section{8. 치스화, 악화와 Lysosome}

치느화라는 것은 조직의 응고계 사의 일종이다. 즉 완 건한 Autolysis나 Autophagy에 의해서 소화 분해되지 못한 상태이다.

결핵균은 lysosome의 활성화를 일으키지 않고 일종의 켱화공존 상태로 지낼 수가 있기 빼문에 치스화가 일어 날 수 있다고 할 수 있다.

그러므로 어떠한 방법으로 lysosome을 활성화 시킬 수 있다면 치스화명변을 인위적으로 액화시켜서 배제핟 수가 있을 것이고 이렇게 되면 결핵치료에 있어서 새로 운 단계가 이루어질 것이라고 하겠다.

〈초역자 첨가〉 치스화는 결핵균이 많이 포할하고 있 는 phospholipids가 단백분해호소의 작용을 저해하기 때 문인지 결핵명변의 주오성분인 단핵세포가 단백분해호 소를 충분히 포함하지 못하고 있기 매문인지는 혹은 그 의의 이유인지는 아직 미해결이지 만 치스화가 액화 공동 령성단계로 되는것은 allergy와 관련성이 있다는 것 보 다는 Pagel의 학설가 같이 외부에서 어뗘한 이유로든지 다핵백혈구가 침윤 대 들어와서 그 풍부한 가수문해효 소의 작용을 나타내기 해문이라고 주장되기도 한다.

그텽다면 치스성명변 근처에 백혈구의 침윤을 많이 갖 어오는 일반세균의 감염이 생기는 일 즉 결핵환자가 굽 성세균성페염 같은 것을 않계 되는·것은 오히러 치스성 병변을 액화해서 배출해 버릴 수 있는 줗은 기회라고도 할 수 있고 따라서 요지부동인 치스화 변화 보다는 공 동성 병변을 갖게 되는 것을 병변의 악화라고 비관적으 로만 해석할 필요는 없을 것 같다. (물론 이배에 층분한 화학요법을 병용하므로서 그 예후가 매우 밝아질 것은 물론이머 이러한 경우나 혹은 대엽폐염성 페결핵 초기 에 있어서 폐염균에 의한 것인지 걸핵균에 의한 것인지 의 구별이 불가능할 때에 폐니실린이나 마찬가지로 폐 열구균에도 살균성이 많고 걸핵균에도 강력한 각옹을 하는 Rifampicin(Rifadin)을 처방하는 것은 매우 합리 적이라고 하갰다.) 